\title{
RESPONSES OF PLASMA ADIPOKINES TO HIGH INTENSITY INTERVAL TRAINING: SYSTEMATIC REVIEW
}

\author{
RESPOSTAS DAS ADIPOCINAS PLASMÁTICAS AO TREINO INTERVALADO DE ALTA INTENSIDADE: \\ REVISÃO SISTEMÁTICA
}

Systematic Review Article

ARTIGO DE REVISÃo SISTEMÁtICA

ARtículo de REVISIÓN SISTEMÁtICA

\author{
RESPUESTAS DE LAS ADIPOCINAS PLASMÁTICAS AL ENTRENAMIENTO POR INTERVALOS DE ALTA \\ INTENSIDAD:REVISIÓN SISTEMÁTICA
}

\section{Geovani Messias da Silva ${ }^{3}$ (iD (Physical Education Professional) Mariane de Oliveira Sandes' (D) (Student on the Nutrition Course) Francisco Sérgio Lopes (iD Vasconcelos-Filho 2,5 (Physical Education Professional) Davi Sousa Rocha' (ID) (Physical Education Professional) Roberta Cristina da Rocha-e-Silva 2,6 (ID (Veterinarian) \\ Carlos Alberto da Silva ${ }^{3}$ (DD (Physical Education Professional) Erica Carneiro Barbosa Chaves ${ }^{4}$ (DD (Physical Education Professional) Ivina Rocha Brito' (ID) (Biologist)}

1. Centro Universitário Estácio do Ceará, Fortaleza, CE, Brazil.

2. Universidade Estadual do Ceará (UECE), Biochemistry and Genetic Expression Laboratory, Instituto Superior de Ciências Biomédicas, Fortaleza, CE, Brazil.

3. Universidade Federal do Ceará (UFC), Instituto de Educação Física e Esportes, Fortaleza, CE, Brazil. 4. Universidade de Fortaleza, Escola de Saúde, Fortaleza, CE, Brazil. 5. Universidade Federal do Cariri, Juazeiro do Norte, CE, Brazil. 6. Faculdade de Juazeiro do Norte, Juazeiro do Norte, CE, Brazil.

\section{Correspondência:}

Geovani Messias da Silva. Rua Luis Torres, 320, Maraponga, Fortaleza, CE, Brasil. 60710-700. geovanimessias@alu.ufc.br

\begin{abstract}
Introduction: Obesity is one of the major diseases of modern times. However, the explanation for its pathophysiology is recent and has not yet been fully elucidated. White adipose tissue synthesizes and secretes adipokines that affect several pathologies related to obesity. Excessive growth of this tissue results in increased levels of pro-inflammatory adipokines and a consequent decrease in anti-inflammatory adipokines. Nevertheless, most studies use moderate intensity training, limiting the understanding of high intensity interval training in these proteins. Objective: To verify the latest information on the effects of HIIT in improving the profile of circulating adipokines. Methods: A search was performed on the databases PUBMED, Lilacs, HighWire, BVS and the Cochrane Database of Systematic Reviews, with the following keywords: HIIT adipokines, HIIT leptin, HIIT adiponectin. Eleven studies were selected, published in English and Portuguese between 2013 and 2017. Results: HIIT proved to be effective in increasing adiponectin in the adolescent population and in Olympic athletes, but this depended on a good prescription parameter and exercise intensity. However, maximum or supramaximal intensities were superior to low and moderate intensities. In turn, leptin presented a significant decrease in response to HIIT due to the reduction of adipose tissue, demonstrating a directly proportional relation. Other adipokines, such as omentin-1 and interleukin-10, also responded positively to HIIT, resulting in improved anti-inflammatory status. Conclusion: HIIT proved to be an efficient method to reduce inflammation due to obesity, as well as inducing an improvement in sports performance. However, the effects depend on training volume, intensity and prescription method. Level of evidence l; Therapeutic study-Investigating the results of treatment.
\end{abstract}

Keywords: Adipokines; Leptin; Adiponectin.

\section{RESUMO}

Introdução: A obesidade é uma das principais doenças dos tempos modernos. Entretanto, a explicação da sua fisiopatologia érecente e ainda não foi totalmente esclarecida. O tecido adiposo branco sintetiza e secreta adipocinas que acometem diversas patologias relacionadas à obesidade. O aumento excessivo desse tecido resulta no aumento dos niveis de adipocinas pró-inflamatórias e na consequente diminuição de adipocinas anti-inflamatórias. Entretanto, a maioria dos estudos utiliza o treinamento de intensidade moderada, limitando o entendimento do treinamento intervalado de alta intensidade nessas proteínas. Objetivo: Verificar as mais recentes informações sobre os efeitos do HIIT na melhoria do perfil das adipocinas circulantes. Métodos: Foi realizada uma pesquisa nos bancos de dados PUBMED, Scielo, Lilacs, HighWire, BVS e Cochrane Database of Systematic Reviews com as seguintes palavras chaves: HIIT adipokines, HIIT leptin, HIIT adiponectin. Onze estudos foram selecionados, publicados em inglês eem português, entre os anos de 2013 e 2017. Resultados: O HIIT mostrou-se eficiente para aumentar a adiponectina na população adolescente e em atletas olímpicos, mas isso depende de um bom parâmetro de prescrição e da intensidade do exercício. Entretanto, as intensidades máximas ou supramáximas se mostraram superiores às intensidades baixas e moderadas. Por sua vez, a leptina apresentou significativa diminuição em resposta ao HIIT devido à redução do tecido adiposo, demonstrando uma relação diretamente proporcional. Outras adipocinas, como a omentina-1 e a literleucina-10, também responderam de forma positiva ao HIIT, resultando em um melhor estado anti-inflamatório. Conclusão: O HIIT demonstrou ser um método eficiente para diminuir a inflamação decorrente da obesidade, assim como induzir uma melhora no rendimento esportivo. Entretanto, os efeitos dependem do volume de treino, intensidade e método de prescrição. Nível de evidência l; Estudo terapêutico-Investigação dos resultados do tratamento.

Descritores: Adipocinas; Leptina: Adiponectina.

\section{RESUMEN}

Introducción: La obesidad es una de las principales enfermedades de los tiempos modernos. Entretanto, la explicación de su fisiopatología es reciente y aún no se ha dilucidado completamente. El tejido adiposo blanco sintetiza y secreta adipocinas que afectan diversas patologías relacionadas a la obesidad. El aumento excesivo de este tejido resulta en el aumento de los niveles de adipocinas proinflamatorias y la consiguiente disminución de las adipocinas 
antiinflamatorias. Entretanto, la mayoría de los estudios usa el entrenamiento de intensidad moderada, limitando el entendimiento del entrenamiento por intervalos de alta intensidad en estas proteínas. Objetivo: Verificar las más recientes informaciones sobre los efectos de HIIT en la mejora del perfil de las adipocinas circulantes. Métodos: Se realizó una búsqueda en los bancos de datos PUBMED, Lilacs, HighWire, BVS y Cochrane Database of Systematic Reviews con las siguientes palabras Ilave: HIIT adipokines, HIIT leptin, HIIT adiponectin. Se seleccionaron 11 estudios, publicados en inglés y portugués entre 2013 y 2017. Resultados: El HIIT se mostró eficiente para aumentar la adiponectina en la población adolescente y en atletas olímpicos, pero eso depende de un buen parámetro de prescripción e intensidad del ejercicio. Entretanto, las intensidades máximas o supramáximas se mostraron superiores a las intensidades bajasy moderadas. A su vez, l leptina presentó disminución significativa en respuesta al HIIT debido a la reducción del tejido adiposo, demostrando una relación directamente proporcional. Otras adipocinas, como omentina-1 e interleucina-10, también respondieron positivamente al HIIT, resultando en un mejor estado antiinflamatorio. Conclusión: El HIIT demostró ser un método eficiente para disminuir la inflamación proveniente de la obesidad, así como inducir una mejora en el rendimiento deportivo. Entretanto, los efectos dependen del volumen de entrenamiento, la intensidad y el método de prescripción. Nivel de evidencia l, Estudio terapéutico - Investigación de los resultados del tratamiento.

Descriptores: Adipoquinas; Leptina; Adiponectina.

\section{INTRODUCTION}

Adipokines are bioactive substances expressed and secreted by adipocytes. Once considered only as a passive tissue that stored excess energy in the form of triacylglycerols, ${ }^{1}$ adipose tissue produces endocrine signaling through these substances. ${ }^{2}$

Adipokines play a crucial role in the pathophysiology of multifactorial metabolic diseases. ${ }^{3}$ Some of these proteins are involved in lipid metabolism, insulin sensitivity, complement system, vascular hemostasis, blood pressure regulation and angiogenesis, as well as energy balance. However, there is a growing list of classical adipokines (TNF-alpha, IL-1b, IL-6, IL-8, IL-10), growth factors (transforming growth factor beta, nerve growth factor) involved in inflammatory processes, as well as deregulation of the acute phase proteins (inhibitor of plasminogen activator-1, haptoglobin and serum amyloid A), all caused by excess adipose tissue. ${ }^{4}$

Leptin and adiponectin are the most abundant adipokines in adipose tissue and perform different functions. Leptin was the first adipocyte-specific hormone to be identified and among its main activities are the control of energy expenditure and the regulation of appetite., 5 Adiponectin has shown effects on the regulation of energy metabolism and insulin sensitivity, ${ }^{7,8}$ as well as in the stimulation of AMP-activated protein kinase (AMPK) in skeletal muscle, ${ }^{9}$ which has been shown to increase the number and mitochondria oxidative capacity. ${ }^{10}$

However, the increase in body adiposity causes a deregulation in the gene expression and secretion of the adipokines, resulting in metabolic dysfunctions. A positive energy balance and sedentary lifestyle lead to the visceral fat accumulation, infiltration of macrophages and pro-inflammatory $T$ cells. The proinflammatory phenotype of M1 macrophage predominates and inflames adipose tissue, which in turn releases proinflammatory adipokines, such as tumor necrosis factor (TNF), causing a mild but significant systemic inflammation. ${ }^{11}$

In obese individuals, resistance to leptin is observed, resulting in an increase in circulating leptin. ${ }^{12}$ Hyperleptinemia can be attributed to decreased transport of leptin to the brain or decreased of hypothalamus leptin signaling. ${ }^{13}$ On the other hand, plasma adiponectin concentration in non-obese individuals is higher (2.5-fold) than in obese individuals. ${ }^{14}$ The relationship between leptin and female sexuality seems to be well defined in the literature, the concentration of leptin is directly related to maturational stages and an inverse relationship with age of menarche, ${ }^{15}$ because the increase in plasma leptin is one of the first signs of initiation and activation of the hypothalamic-pituitary-gonadal (HPG) axis, resulting in increased estrogen and progesterone concentration. ${ }^{15,16}$

Studies have suggested an important role of physical exercise in the regulation of. ${ }^{17-20}$ Among the different modalities, high intensity interval training (HIIT) has been used as a strategy to prevent metabolic syndrome. ${ }^{21}$ HIIT can be characterized by short duration sessions composed of high intensity repetitions, interspersed with active or passive rest ${ }^{22}$. There is evidence that HIIT is able to induce lipolytic hormone secretion, probably by the action of IGF-1 on protein kinase B stimulation and by the signaling of testosterone in the androgen receptor, in addition to increasing oxidative capacity, being directly related to the reduction of metabolic disturbances. ${ }^{23}$

Studies involving the practice of HIIT on the secretion of adipokines have been developed in different populations, especially obese and athletes. ${ }^{24-26}$ Thus, the present work aims to gather the latest information about the effects of different protocols of HIIT on adipokine plasma concentrations.

\section{METHODS}

In order to organize this systematic review, a search was made in the databases PUBMED, Lilacs, HighWire, BVS and Cochrane Database of Systematic Reviews with the following keywords: HIIT adipokines, HIIT leptin, HIIT adiponectin.

We found 13 articles, published in English and Portuguese between 2013 and 2017. Of these, 11 were selected after a selective reading to assess whether the topic of the article was pertinent to the present review, followed by an exploratory reading, where we sought to read and interpret the data present in the studies (Figure 1). Quality assessment was conducted using the Physiotherapy Evidence Database (PEDro) scale. The PEDro scale awards a score out of 10 based on criteria described elsewhere. For a better understanding of the data, classic studies were used in the discussion.

\section{RESULTS AND DISCUSSIONS}

Studies that sought to assess the effects of HIIT on plasma adipokine levels are shown in Table 1. There are few jobs in this area, in addition, the various ways of using the method (eg ergometer rowing, cycle ergometer, outdoor all-out shots) make it difficult to analyze on a training basis. However, all studies reported here have demonstrated the effectiveness of HIIT as a method for the prevention or treatment of metabolic disorders caused by sedentary lifestyle and obesity or improvement of adipokines related to sports performance, such as adiponectin. ${ }^{27-30,24,31-33}$ 


\section{Effects of HIIT on adipokine plasma concentrations}

\section{Adiponectin}

Adiponectin has shown an inverse relationship with visceral fat, ${ }^{1}$ this can be explained by tumor necrosis factor (TNF-a) has been reported as a strong inhibitor of the action promoted by adiponectin. ${ }^{34}$ Other proinflammatory cytokines regulate the anti-inflammatory activity of adiponectin, specifically interleukin-6 (IL-6) and C-reactive protein (CRP); TNF-alpha and adiponectin are mutually inhibited; the expression of PCR is down-regulated by adiponectin; the expression of adiponectin is suppressed by IL-6. ${ }^{35}$ Low levels of plasma adiponectin have been found in type 2 diabetics, ${ }^{36}$ suggesting that adiponectin is an important hormonal factor in the control of insulin sensitivity. Most of the interventions occurred with female adolescents, where adiponectin changed positively at that age when HIIT occurred three times a week for 12 weeks, ${ }^{32}$ but did not change when the frequency was twice a week

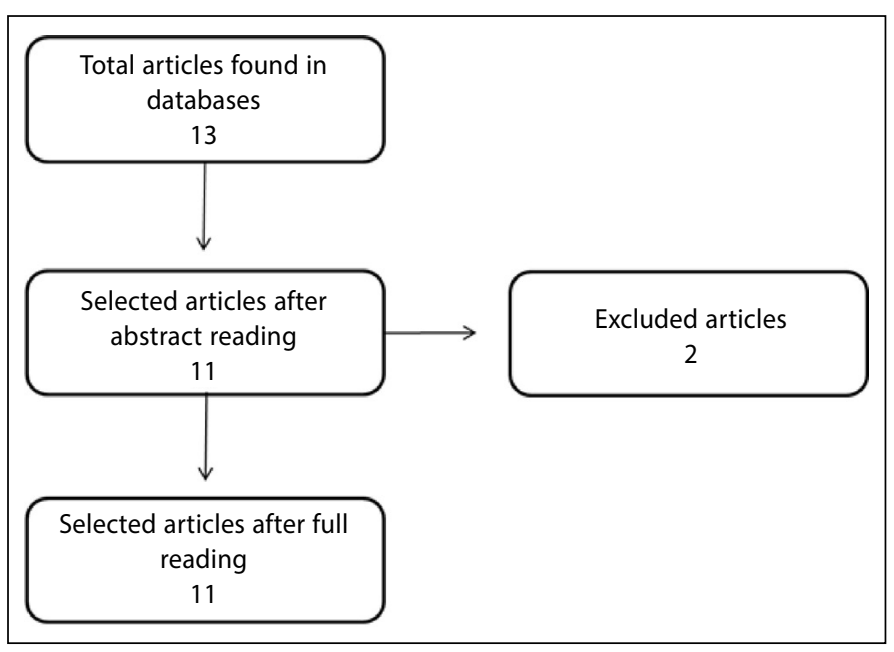

Figure 1. Sequence of searching and search results. for six months. ${ }^{29}$ The difference in the result may also have occurred due to a singularity in the training performed by Racil et al. ${ }^{32}$ because his protocol had increases in speed every four weeks, which was not specified by Blüher et al. ${ }^{29}$ where the intensity increase depended on the improvement in heart rate.

The combination of HIIT with plyometric training also seems to result in positive effects on leptin and adiponectin. ${ }^{24}$ Racil et al. ${ }^{24}$ distributed 68 obese adolescents in 3 groups: HIIT, plyometry + HIIT and control, all trained three times a week for twelve weeks (with the exception of the control). The group that used plyometric exercise in conjunction with HIIT had superior effects to the group that only did HIIT in the percentage of fat-free mass, in the plasma concentration of leptin, glucose and adiponectin, leptin-adiponectin ratio, HOMAR-IR and Squat Jump. Thus, the author concluded the efficacy of HIIT in obese female adolescents, but recommends the use of plyometric exercises to improve the adaptations.

It is interesting to note that adiponectin appears to respond positively to HIIT when it is prescribed from maximal aerobic velocity, ${ }^{32,24}$ but not when maximal heart rate (HRmax) is used. ${ }^{29,31}$ Another interesting observation is that the first two studies used maximum or "supramaximal" intensities, the latter two using submaximal intensities. In addition, there was monitoring of the respiratory exchange rate (RER) during the pre-training tests when adiponectin responded positively, 32,24 but not when it did not change or responded negatively. ${ }^{29,31}$ This fact can be explained by the training intensity is more accurately monitored when the intensity related to the anaerobic threshold (Lan) is known, which can be estimated by the RER, but the HRmax is not a strong predictor of the Lan at all intensities.

Meyer, Gabriel, Kindermann et al. ${ }^{37}$ have shown that the prescription from the HRmax can vary depending on the individual. The individual anaerobic threshold (IAT) ranged from 53 to $85 \%$ when the heart rate was at $70 \%$ of the HRmax and ranged from 87 to $116 \%$ of the IAT when the heart rate was at $85 \%$ of the HRmax. These data show that HRmax-only prescription can cause high or supramaximal intensities in different individuals, even if they are in the same percentage of HRmax.

Table 1. Selected studies according to the presented method.

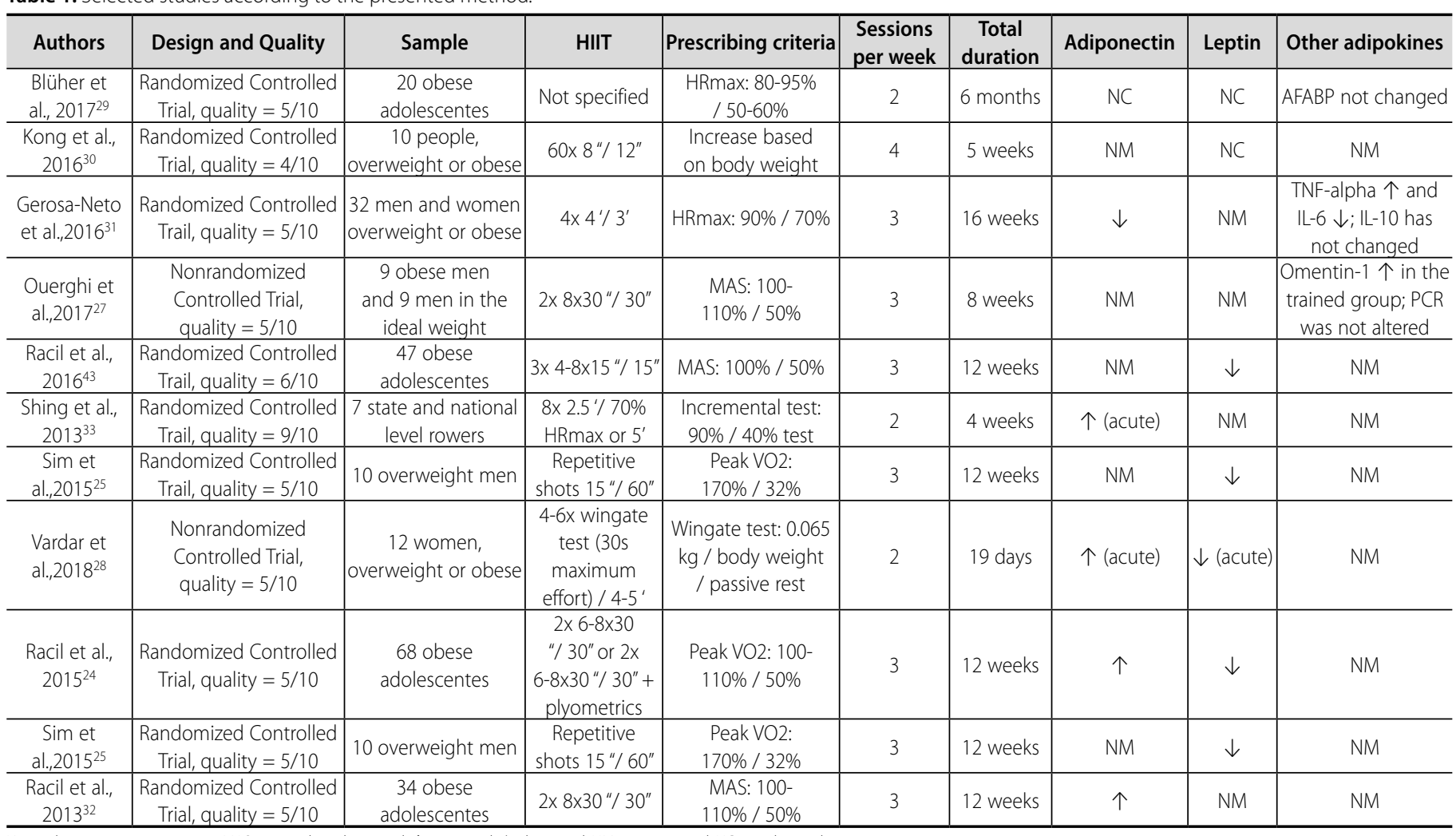


Adiponectin has also been studied as a performance marker. Juramae et al. ${ }^{26}$ reported that rowers selected to represent the Olympic team had increases in circulating adiponectin after a maximum of 2000 meters, since the unselected rowers had a decrease in circulating adiponectin. This is possibly due to the effect of adiponectin on bioenergetic function, such as: AMPK activity and increase of PGC1-alpha, leading to consequent mitochondrial biogenesis. Shing et al. ${ }^{33}$ tested the effect of HIIT on state and national level rowers for four weeks, training consisted of $90 \%$ of the effort measured through an incremental test (TI) for two minutes and thirty seconds, intercalated by recovery to $40 \%$ of the effort reached in $\mathrm{TI}$ until the heart rate returned to $70 \%$ of maximum or reached a maximum of 5 minutes of active recovery. The training was performed in a rowing ergometer to facilitate the adaptation of the athletes. At the end of the intervention the adiponectin improved in acute response to exercise and a broad but non-statistically improvement in adiponectin at rest was observed. The study also included a group with a traditional training ranging from 35 to 40 minutes, corresponding to the intensity reached at a lactate concentration of 2 to $3 \mathrm{mmol} / \mathrm{L}$. But this group did not experience any significant difference in post-exercise adiponectin or adiponectin at rest.

These data can be interpreted in two ways, HIIT may have been superior to traditional training in improving the concentration of adiponectin, because it had a much greater intensity per unit of time or the athletes responded better due change in their exercise routine mediated by HIIT. The authors also recommended that further studies be conducted to clarify the relationship of the increase of adiponectin with various physiological adaptations observed, such as decreased fat mass and increased Vo2max in the HIIT group, but not in the traditional training group. ${ }^{33}$

\section{Leptin}

The effect of HIIT on the plasma concentration of leptin is not yet fully elucidated because the findings are controversial, with a decrease in plasma concentration in some studies. ${ }^{24,25,24,28}$ While it doesn't present modifications in others. ${ }^{29,30}$

In studies where leptin declined there was a decrease in fat mass, which did not occur when it remained unchanged. This suggests that the decay of resting leptin is closely linked to the reduction of fat mass. However, Blüher et al. ${ }^{29}$ demonstrated that leptin remained unchanged even with fat mass reduction, this may have occurred because the fat mass percentage was too high before training and even with the post training decrease, was not enough to produce significant improvements in leptin concentration.

Despite the previously mentioned effect of leptin, such as regulating appetite and increasing fatty acid oxidation, obese people do not seem to respond in a manner analogous to eutrophic persons. High plasma concentrations of leptin are associated with the same resistance, this can be caused by problems in the transport through the blood-brain barrier and impaired leptin neural signaling in the target neurons. ${ }^{38}$ Considine et al. ${ }^{39}$ reported that although the leptin concentration increases directly proportional to the percentage of fat mass, obese individuals have insensitivity to the endogenous production of the same. This fact corroborates the indications of failure of the leptin mechanism of action when its plasma concentration rises. ${ }^{37}$

Thus, it is interesting that leptin concentrations decrease in response to training, since this may be indicative of an improvement in energy metabolism or reduction of fat mass. In addition, it seems to be related to the improvement of peripheral insulin sensitivity (skeletal muscle) and modulation of pancreatic $\beta$-cell function, ${ }^{12}$ thus avoiding the development of type 2 diabetes.

\section{Other adipokines}

Some studies have found other adipokines such as TNF-alpha, IL-6, IL-10, ${ }^{31}$ omentin-1 and C-reactive protein (CRP) adipocyte fat (aFABP). ${ }^{27}$ The first study showed that pro-inflammatory markers, such as TNF-alpha and IL-6, increased and decreased, respectively. However, anti-inflammatory markers, such as IL-10 and adiponectin, did not change or decrease, respectively. However Gerosa-Neto et al. ${ }^{31}$ used as a predictive factor of training, which facilitates symptoms of nonfunctional overreaching and may lead to an inflammatory status.

Omentin-1 is a recently discovered adipokine, secreted primarily by visceral adipose tissue and has high expression in the adipose tissue of the stroma of vascular cells. ${ }^{33}$ It has been shown to improve insulin-mediated glucose transport and also to stimulate ATK phosphorylation in adipocytes, leading to the belief that it improves insulin sensitivity.40,27 On the other hand, CRP is a marker for the risk of cardiovascular diseases, also showing a strong predictor of future acute myocardial infarction. ${ }^{41}$

Ouerghi et al., ${ }^{27}$ showed that HIIT training increased omentin-1 concentrations in obese individuals higher than those in the normal weight, but did not change the concentration of plasma PCR. The most pronounced improvement in obese individuals may be related to the decrease in body mass index (BMI) and fat mass in these individuals, which did not occur in people with normal weight. The authors also observed a positive relationship of omentin-1 with BMI, total cholesterol and Vo2max, but negatively with LDL-cholesterol and fat mass. However, it did not show any relation with HOMAR-IR, although this index has decreased in obese people.

aFABP is the main protein in the cytoplasm of mature adipocytes and macrophages, and is recognized as a key protein that binds factors such as obesity, diabetes and atherosclerosis. ${ }^{42}$ This adipokine is also related to the regulation of intracellular transport of fatty acids and in the pathogenesis of the metabolic syndrome. High production rates of aFABP are related to increased cholesterol and accumulation of triacylglycerols, as well as increased expression of pro-inflammatory markers Ridker PM. ${ }^{29}$ High-sensitivity C-reactive protein: potential adjunct for global risk assessment in the primary prevention of cardiovascular disease.

Blüher et al. ${ }^{29}$ showed that aFABP did not change in response to HIIT, for a better understanding of the relationship of this adipocin with exercise, further research is needed.

In summary, due to the different methodological designs of HIIT and different samples, the data vary greatly (Figure 2). Obesity leads to deregulation of serum concentrations of various adipokines that will act on various

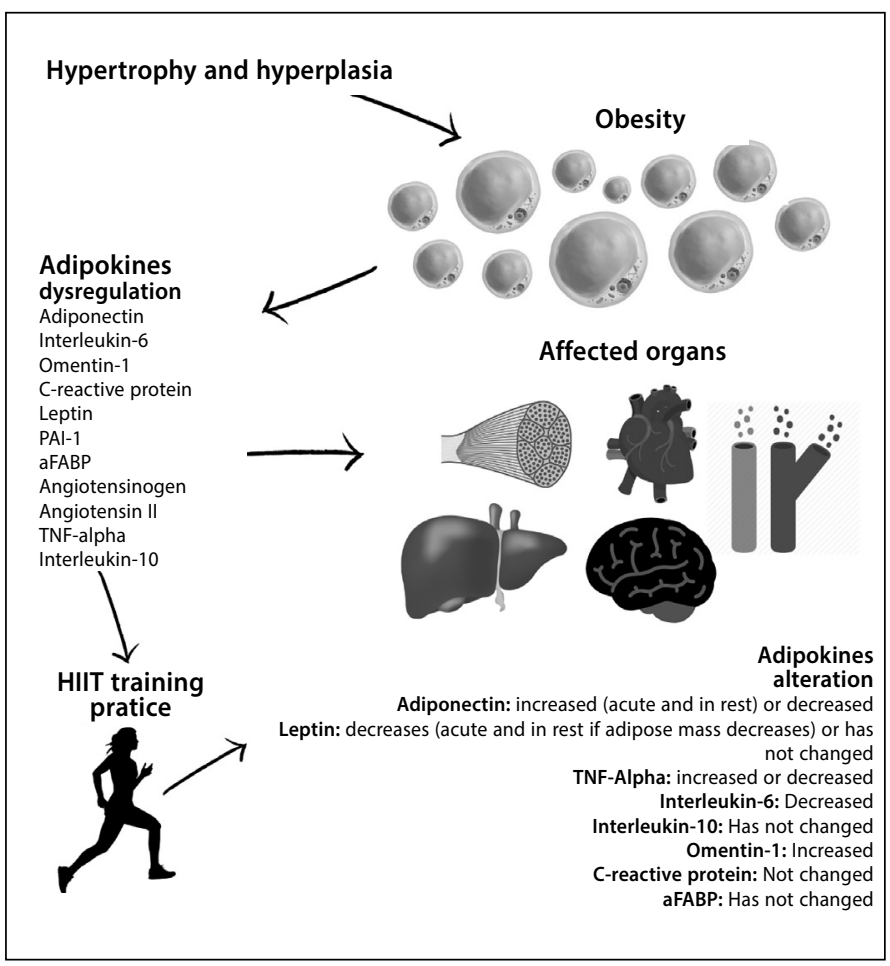

Figure 2. Overview of obesity adipokine dysregulation and the HIIT therapeutic effects 
organs causing detrimental effects on morphology and function. HIIT acts as a noninvasive therapeutic agent that improves the concentration of various adipokines in the blood, which can prevent such tissue damage.

\section{CONCLUSION}

The present review found that HIIT is an interesting methodology to be recommended in the treatment or prevention of the metabolic syndrome, because it acts directly on the physiological factors that lead to this condition. However, HIIT demonstrated only significant effects on adipokine plasma concentrations when it was prescribed at near-maximal, maximal or supramaximal intensity, so the intensity needs to be controlled by precise techniques, such as lactate concentration or ratio of respiratory exchange.

In a practical approach, HIIT appears to be a viable choice for reducing inflammation due to obesity even if no fat loss occurs. However, more studies are needed to provide health professionals, especially Physical Education, with a better understanding of the processes that mediate these responses, thus helping to apply more efficient protocols.

All authors declare no potential conflict of interest related to this article

AUTHORS' CONTRIBUTIONS: Each author made significant individual contributions to this manuscript. GMS: writing, review, research in databases and preparation of the entire research project; IRB: analysis of the data, and writing; FSLVF: translation and review; RCRS and CAS: review; ECBC: writing; MOS: writing and standardization to the rules of the journal; DSR: writing and review. All the authors reviewed and approved the final version of the manuscript.

\section{REFERENCES}

1. Matsuzawa Y, Funahashi T, Nakamura T. The concept of metabolic syndrome: contribution of visceral fat accumulation and its molecular mechanism. J Atheroscler Thromb. 2011;18(6): 629-39.

2. Picu A, Petcu L, Stefan S, Mitu M, Lixandru D, lonescu-Tirgovise C, et al. Markers of oxidative stress and antioxidant defense in romanian patients with type 2 diabetes mellitus and obesity. Molecules. 2017;22(5):714-28

3. Knebel B, Goeddeke S, Poschmann G, Markgraf DF, Jacob S, Nitzgen U, et al. Novel Insights into the Adipokinome of Obese and Obese/Diabetic Mouse Models. Int J Mol Sci. 2017;18(9):pii: E1928.

4. Trayhurn P, Wood IS. Adipokines: inflammation and the pleiotropic role of white adipose tissue. Br J Nutr. 2004;92(3):347-55.

5. Zhang Y, Proenca R, Maffie M, Barone M, Leopold L, Friedman JM. Positional cloning of the mouse obese gene and its human homologue. Nature. 1994;372(6505):425-32.

6. Campfield LA, Smith FJ, Guisez Y, Devos R, Burn P. Recombinant mouse OB protein: evidence for a peripheral signal linking adiposity and central neural networks. Science, 1995;269(5223):546-9.

7. Wang Y, Lam JB, Lam KS, Liu J, Lam MC, Hoo RL, et al. Adiponectin modulates the glycogen synthase kinase-3beta/beta-catenin signaling pathway and attenuates mammary tumorigenesis of MDA-MB-231 cells in nude mice. Cancer Res. 2006;66(23):11462-70.

8. Lafontan M, Viguerie N. Role of adipokines in the control of energy metabolism: focus on adiponectin. Curr Opin Pharmacol. 2006;6(6):580-5.

9. Dyck DJ, Heigenhauser GJ, Bruce CR. The role of adipokines as regulators of skeletal muscle fatty acid metabolism and insulin sensitivity. Acta Physiol (Oxf). 2006;186(1):5-16.

10. Ojuka EO. Role of calcium and AMP kinase in the regulation of mitochondrial biogenesis and GLUT4 levels in muscle. Proc Nutr Soc. 2004;63(2):275-8.

11. Gleeson M, Bishop NC, Stensel DJ, Lindley MR, Mastana SS, Nimmo MA. The anti-inflamatory effects of exercise: mechanisms and implications for prevention and treatment of disease. Nat Rev Immunol. 2011;11(9):607-15.

12. Yadav A, Kataria MA, Saini V, Yadav A. Role of leptin and adiponectin in insulin resistance. Clin Chim Acta. 2013;417:80-4

13. Münzberg H, Myers MG Jr. Molecular and anatomical determinants of central leptin resistance. Nat Neurosci. 2005;8(5):566-70

14. Arita Y, Kihara S, Ouchi N, Takahashi M, Maeda K, Miyagawa J, et al. Paradoxical decrease of an adiposespecic protein, adiponectin, in obesity. Biochem Biophys Res Commun. 1999;257(1):79-83.

15. Meira TB, Moraes FL, Böhme MT. Relações entre leptina, puberdade e exercício no sexo feminino. Rev Bras Med Esporte. 2009;15(4):306-10

16. Moschos S, Chan JL, Mantzoros CS. Leptin and reproduction: a review. Fertil Steril. 2002;77(3):433-44.

17. Algul S, Ozdenk C, Ozcelik O. Variations in leptin, nesfatin-1 and irisin levels induced by aerobic exercise in young trained and untrained male subjects. Biol Sport. 2017;34(4):339-44.

18. Kang SJ, Kim JH, Gang Z, Yook YS, Yoon JR, Ha GC, et al. Effects of 12-week circuit exercise program on obesity index, appetite regulating hormones, and insulin resistance in middle-aged obese females. J Phys Ther Sci. 2018;30(1):169-73.

19. Leggate M, Determination of inflammatory and prominent proteomic changes in plasma and adipose tissue after high-intensity intermittent training in overweight and obese males. J Appl Physiol. 2012;112(8):1353-60.

20. Suárez-García S, Del Bas JM, Caimari A, Escorihuela RM, Arola L, Suárez M. Impact of a cafeteria diet and daily physical training on the rat serum metabolome. Plos One. 2017;12(2): e0171970.

21. Tjonna AE, Lee SJ, Rognmo O, Stolen TO, Bye A, Haram PM, et al. Aerobic interval training versus continuous moderate exercise as a treatment for the metabolic syndrome: a pilot study. Circulation. 2008;118(4):346-54

22. Boyle M. Avanços no treinamento funcional. Porto alegre: Artmed, 2015. p. 256.

23. Irving, Brian A. et al. Effect of Exercise Training Intensity on Abdominal Visceral Fat and Body Composition. Medicine \& Science In Sports \& Exercise. 2008;40(11):1863-72

24. Racil, Ghazi \& ZOUHAL, Hassane \& Elmontassar, Wassim \& Abderrahman, Abderraouf \& Sousa, Maysa \& Chamari, Karim \& Mohamed, Amri \& Coquart, Jeremy. (2015). Plyometric exercise combined with high-intensity interval training improves metabolic abnormalities in young obese females more so than interval training alone. Applied Physiology, Nutrition, and Metabolism. 41. 10.1139/ apnm-2015-0384.

25. Sim AY, Wallman KE, Fairchild TJ, Guelfi KJ. Effects of high-intensity intermittent exercise training on appetite regulation. Med Sci Sports Exerc. 2015;47(11):2441-9.

26. Jurimae J, Purge $P$, Jurimae T. Adiponectin and stress hormone responses to maximal sculling after volume-extended training season in elite rowers. Metabolism. 2006;55(1):13-9.

27. Ouerghi N, Ben Fradj MK, Bezrati I, Feki M, Kaabachi N, Bouassida A. Effect of High-Intensity Interva Training on Plasma Omentin-1 Concentration in Overweight/Obese and Normal-Weight Youth. Obes Facts. 2017;10(4):323-31.

28. Vardar SA, Karaca A, Güldiken S, Palabıyık O, Süt N, Demir AM. High-intensity interval training acutely alters plasma adipokine levels in young overweight/obese women. Arch Physiol Biochem 2018;124(2):149-55.

29. Blüher S, Kläpplinger J, Herget S, Reichardt S, Böttcher Y, Grimm A, et al. Cardiometabolic risk markers, adipocyte fatty acid binding protein (aFABP) and the impact of high-intensity interval training (HIIT) in obese adolescents. Metabolism. 2017;68:77-87.

30. Kong Z, Sun S, Liu M, Shi Q. Short-Term High-Intensity interval training on body composition and blood glucose in overweight and obese young women. J Diabetes Res. 2016;2016:4073618.

31. Gerosa-Neto J, Antunes BM, Campos EZ, Rodrigues J, Ferrari GD, Rosa Neto JC, et al. Impact of long-term high-intensity interval and moderate-intensity continuous training on subclinical inflammation in overweight/obese adults. J Exerc Rehabil. 2016;12(6):575-80.

32. Racil G, Ben Ounis O, Hammouda O, Kallel A, Zouhal H, Chamari K, et al. Effects of high vs. Moderate exercise intensity during interval training on lipids and adiponectin levels in obese young females. Eur J Appl Physiol. 2013;113(10):2531-40

33. Shing CM, Webb JJ, Driller MW, Williams AD, Fell JW. Circulating adiponectin concentration and body composition are altered in response to high-intensity interval training. J Strength Cond Res. 2013:27(8):2213-8

34. Maeda N, Takahashi M, Funahashi T, Kihara S, Nishizawa H, Kishida K, et al. PPARgamma ligands in crease expression and plasma concentrations of adiponectin, an adipose-derived protein. Diabetes. 2001;50(9):2094-9.

35. Prado WL, Lofrano MC, Oyama LM, Dâmaso AR. Obesidade e adipocinas inflamatórias: implicaçōes práticas para a prescrição de exercício. Rev Bras Med Esporte. 2009 [access in 16 dec 2017];15(5):378-83. Available in: http://www.scielo.br/scielo.php?pid=\$1517 $86922009000600012 \&$ script=sci_abstract\&tlng=pt

36. Hotta K, Funahashi T, Arita Y, Takahashi M, Matsuda M, Okamoto Y, et al. Plasma concentrations of a novel, adipose-specific protein, adiponectin, in type 2 diabetic patients. Arterioscler Thromb Vasc Biol. 2000;20(6):1595-9.

37. Meyer, Tim \& Gabriel, Holger \& KINDERMANN, WILFRIED. (1999). Is determination of exercise intensities as percentages of VO2max or HRmax adequate?. Medicine \& Science in Sports \& Exercise. 31. 1342-1345

38. Leal VO, Mafra D. Adipokines in obesity. Clinica Chim Acta. 2013;419:87-94.

39. CONSIDINE, RobertV. et al. Serum Immunoreactive-Leptin Concentrations in Normal-Weight and Obese Humans. New England Journal Of Medicine. 1996;334(5): 292-5

40. Yang RZ, Lee MJ, Hu H, Pray J, Wu HB, Hansen BC, et al. Identification of omentin as a novel depot-specific adipokine in human adipose tissue: possible role in modulating insulin action. Am J Physiol Endocrino Metab. 2006;290(6): E1253-61

41. Ridker PM. High-sensitivity C-reactive protein: potential adjunct for global risk assessment in the primary prevention of cardiovascular disease. Circulation. 2001;103(13):1813-8.

42. Hao Y, Ma X, Luo Y, Hu X, Pan X, Xiao Y, et al. Associations of serum adipocyte fatty acid binding protein with body composition and fat distribution in nondiabetic Chinese women. J Clin Endocrino Metab. 2015;100(5):2055-62

43. Racil G, Coquart JB, Elmontassar W, Haddad M, Goebel R, Chaouachi A, et al. Greater effects of high- compared with moderate-intensity interval training on cardio-metabolic variables, blood leptin concentration and ratings of perceived exertion in obese adolescent females. Biol Sport. 2016;33(2):145-52 